\title{
A longitudinal study of a reading project in the Northern Cape, South Africa
}

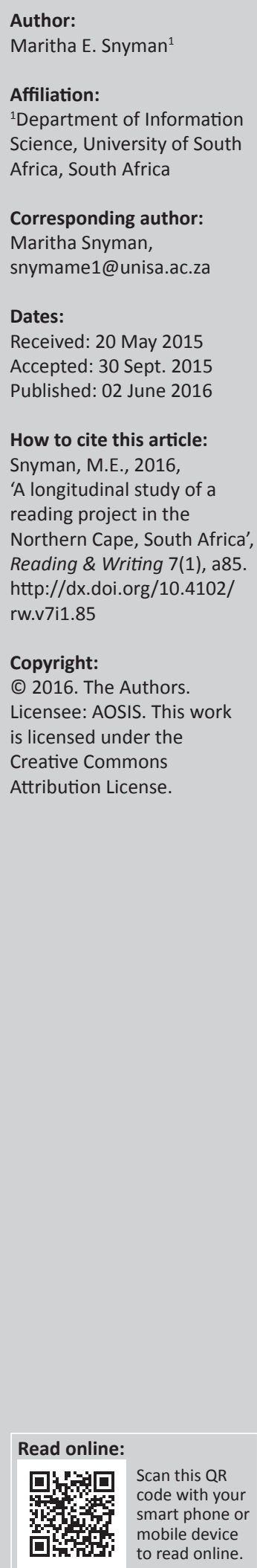

The topic of this longitudinal study was reading promotion and its perceived benefits. The aim was to determine if reading promotion can lead to reader development and if reader development can lead to self-development, as is often claimed in the literature. A reading promotion project in the Northern Cape, South Africa, was monitored over a period of five years by using a selection of qualitative and quantitative data collection methods. The outcome of the study indicates that the reading promotion project was responsible for positive changes in the lives of the beneficiaries of the intervention. It especially points to the positive role access to appropriate reading material and prolonged and enthusiastic reading motivation can play in the lives of a developing community with little means.

\section{Introduction}

'Reading in decline in South Africa'; 'SA schools at rock bottom in international assessments'; 'South Africa is a nation of dunces, international comparisons show'; 'Too late to fix for next generation?' shout the media headlines every time the results of the international benchmarking test, PIRLS ${ }^{1}$, are announced. Journalists and educationists comment about and lament the dangerously low levels of South African learners' reading skills.

And dangerously low they are. In 2012 the national average for literacy at Grade 4 was 34\% and at Grade 6, 28\% [Department of Basic Education (DBE) 2012:22]. Spaull (2013) indicates that SACMEQ2 which evaluated Grade 6 literacy from 2000 to 2007, found that $27 \%$ of South African Grade 6 pupils were illiterate, because they could not read a short and simple text and extract meaning from it.

The South African Book Development Council (SBDC) (2007:4-135) paints a similarly bleak picture of the reading habits of adult South Africans. More than half of South Africa's population do not have any books in the home (SBDC 2007:66). Only 26\% read daily in their leisure time, and newspapers are their favourite reading material. Books amount to only $38 \%$ of reading matter. These figures are responsible for the classification of South African adults as 'infrequent readers' (SBDC 2007:53).

Usually the flutter in the media about declining literacy figures quickly dies away in the wake of more important news, until the results of the next test are announced. 'Silently reading and writing skills are declining in South Africa' (Spaull 2013). In any society dominated by the written word, reading is a fundamental requirement for participation in community life. Literacy skills are crucial to parenting, employment seeking, consuming, and so on (EU High Level Group of Experts on Literacy 2012:12). Reading not only impacts everyday life, but it is also at the heart of self-education and lifelong learning (Cox \& Guthrie 2001:129). It is also needed to take advantage of digital developments. A literate individual can 'develop capacities of reflection, critique and empathy' (EU High Level Group of Experts on Literacy 2012:12) that consequently lead to a sense of self-efficacy and identity.

Most South Africans do not have easy access to books (Mulgrew 2012:14). Only 46\% can access books from libraries (SBDC 2007:74). Thirty libraries per million people are not sufficient for a population of more than 40 million people (KPMG 2008:5). The skewed distribution of libraries from the apartheid era remains. The Library and Information Services Transformation Charter [Department of Arts and Culture (DAC) 2014] acknowledges that there is no 'national strategy to guide the development of the LIS sector as a whole [and that there is a] big disparity between sub sectors' (DAC 2014:13). School libraries are also in a dismal state. Less than 10\% of South African schools have a functional library (Equal Education 2009:4). According to Hart and Nassimbeni (2013:16) '[ $t$ ] he stark reality is that the South African school library sub-system is close to extinction'.

1.Progress in International Reading Literacy Study.

2.The Southern and Eastern African Consortium for Monitoring Educational Quality. 
Apart from the global negative impact of television and the Internet on reading (Gallagher 2009; Mokhtari, Reichard \& Gardner 2009), other barriers to reading in South Africa include systemic weaknesses in the basic education system and multilingualism (Machet \& Tiemensma 2009; Pretorius \& Currin 2010).

To create a love of reading should become a priority in South Africa. It has often been stated that people only engage in reading regularly if they have developed a love of reading and are '[e]nthusiastic and habitual' readers (Bayless 2010:9). It is believed that reading for leisure develops critical perception and conceptual thinking, which lead to self-development (Cox \& Guthrie 2001:129). According to Phasha, McLure and Magano (2012:322), leisure reading facilitates communication, expands general knowledge and impacts on academic success.

It is clearly important to promote leisure reading in the South African context. Reading should be advocated as a pleasurable activity and as a valuable skill. There is, furthermore, no evidence that the South African government is actively trying to reverse the decline in reading skills through methods such as providing access to books and advocating a love of reading.

To counteract the DBE and DAC's general inability to turn around the declining literacy levels, various nongovernmental organisations and private institutions and enterprises, often in collaboration with the government, try to help build the reading capacity of South Africa's future generations by initiating reading promotion projects of various types in various areas (Chizwina 2011).

This article reports on a reading promotion project that was established in 2009. The project was closely monitored over a period of five years to determine how it benefited the beneficiaries of the project, if at all. Determining whether the promotion of leisure reading can lead to a reading culture also came under scrutiny in this project.

\section{Reading promotion}

It is universally believed that reading promotion projects can create an appetite for reading (Doiron \& Asselin 2011:113). There is, for instance, a lengthy tradition of reading promotion in the United Kingdom, where enterprising and imaginative methods are used to promote reading (Elkin, Train \& Denham 2003).

In essence reading promotion refers to any campaign, event, programme, initiative or library service that has the aim to promote reading. Reading promotion 'seeks to provide conducive reading environments and copious reading activities' (Olaofe 2003:97). Reading promotion not only wants to motivate people to read, it also wants to help them to develop pleasure in reading and to increase their reading enjoyment.

A reading promotion campaign can focus on any segment of the population. Its aim is to create an environment that permits access to books, regardless of location, educational level, economic status, race or religion. Ultimately, it wants to develop a reading culture by introducing non-traditional readers to books and helping them find the joy of reading (Elkin et al. 2003:2).

\section{Reading promotion: A two-step approach}

All reading promotion projects entail a two-step approach.

Easy access to books at any time is the first step if reading habits are to be improved (Oyegade 2012:59). Often the lack of a reading culture in a community is caused by 'the lack of conducive reading environments supported with relevant resource materials' (Oyegade 2012:61). Access to books must be the first outcome of reading promotion; therefore reading promotion is also the promotion of access to reading material (Rosi 2005:13).

Books alone, however, are not enough. A second step must be taken. Once books are available, a mediator or facilitator must help the reader to find the joy of reading. This is referred to as reader development. A triangular relationship between 'the reader, the text and the interaction between the two' must take place (Elkin et al. 2003:59) and this interaction must benefit the reader. Strategies exist on how to develop reading fluency and comprehension. 'Agents of change' (Leadbeater 2003) are needed 'to promote the skills, and even more importantly, the appetite for reading' (Department of Culture, Media and Sport 2003:24).

Apart from providing books, reading promotion should also aim to develop readers by improving their reading experience. Reader development, ipso facto, needs enthusiastic intermediaries or facilitators who can unlock the pleasure of reading to establish a lifelong reading habit (Benevides \& Peterson 2010:291).

\section{Reading promotion as a social activity}

Pleasurable reading sometimes occurs in social settings. Social activity around books enhances the reading experience. Reading clubs have proven to be very successful reading promotion tools. Membership in a popular reading club can have a positive impact on its members' self-esteem and behaviour.

\section{Reading promotion in South Africa}

Reading promotion projects can help to counteract the decline of readership in South Africa. The Project for the Study of Alternative Education in South Africa (PRAESA) ${ }^{3}$ and others showed that 'when relevant and exciting literature is made accessible, differences can be made' (Mulgrew 2012:14). Chizwina (2011) identified 77 reading promotion projects in South Africa that aim to make a difference.

3.Focusing on the joy of reading, PRAESA manages projects like Little Hands books, the Vulindlela Reading Club and the national reading promotion initiative Nal'ibali. the Vulindlela Reading Club and the national reading promo
In 2015 they received the Astrid Lindgren Memorial Award. 


\section{Conducting the study}

\section{Aim of the study}

The establishment of a direct link between a reading promotion project and reader development is needed to motivate more players to engage in reading promotion projects.

The aim of this article is therefore to report on a reading promotion project by investigating the perceived value of reading promotion and, if possible, determine whether reader development can be linked to self-development. To be able to do this, a reading promotion project was conceptualised and established. It had to be carefully monitored to trace the effects of this intervention on beneficiaries over a period of time.

\section{The location of the reading promotion project}

The researcher had access to small developing communities in and around Upington, South Africa. A children's book author and inhabitant of this area, Anzil Kulsen, eagerly offered her services as coordinator of the proposed project. The government of Antwerp Province in Belgium was willing to fund a reading promotion project in this area. These factors decided the location of the reading promotion project, namely the small settlements in and around Upington.

Upington is one of the bigger towns in the Northern Cape region and the main town of the / / Khara Hais municipality, which incorporates seven small rural settlements, namely Karos, Leerkrans, Leseding, Raaswater, Sesbrugge, Klippunt and Kalksloot (The Local Government Handbook 2015:1). Only 2.2\% of the South African population resides in the arid Northern Cape (SouthAfrica.info 2015).

The majority of the people of / / Kara Hais are poor. Nearly half of the population (42.8\%) have an income below the poverty breadline of R800.00 (ITS \& Sanral 2007:7). Only $26.9 \%$ of the inhabitants are economically active (//Khara Hais Municipality 2014:6). A downward spiral of poverty is indicated by a decrease in the number of formal dwellings and a constant unemployment rate of 34\% (// Khara Hais Municipality 2014:6).

These settlements have no access to books. They are situated between 20 and 50 kilometres from Upington and Keimoes, where libraries are located, but the inhabitants have neither transport nor means to reach these libraries. Walking is their main form of transport. ${ }^{4}$ At the time of the establishment of this project there was no other reading promotion in this area.

\section{Research population}

Most of the population (65.2\%) is of mixed race and $85.2 \%$ speak Afrikaans as their first language. Female households dominate (34.1\%) (ITS \& SANRAL 2007:6) and women are the main caregivers and providers for children (//Khara Hais Municipality 2014:8). Yet the status and self-image of women are low. Although most reading promotion projects in South Africa are focused on children (Chizwina 2011:100), meeting the women in the small isolated settlements exposed their vulnerability and the need for a positive intervention in their lives.

Women, and specifically Afrikaans-speaking women of mixed race who live in the small settlements in and around Upington, were identified as the beneficiaries for the reading promotion project. They were informed at the beginning of the project that the reading project would also be a research project and they consented to becoming part of the project.

\section{Conceptualisation of the reading promotion project}

Since the aim of this reading promotion project was to investigate the value of reading in a community, the conceptualisation, establishment and management of the project had to be carefully structured and regulated to enable the researcher to collect reliable data. The research aim required a long-term reading promotion project. Short-term projects seem to have fewer permanent effects (Malmgren \& Leone 2000:246), because behaviour change takes time.

The project plan was conceptualised as follows:

- The coordinator, Anzil Kulsen, would establish reading clubs in as many rural settlements as funding allowed.

- Each club would receive 50 new romances ${ }^{5}$ as a start-up pack.

- At each club a facilitator would be selected and trained to organize the monthly club meetings.

- During monthly meetings the coordinator would be present, oversee the meeting, distribute the books and keep record of the books, attendance of members and noticeable events on a specially designed form.

- The researcher would source enough funds to pay, at a minimum, the salary of the coordinator. The coordinator also had to collaborate with the wider community in order to find more funds and support.

- The coordinator had to write monthly and yearly reports about what she considered milestones in the project, according to prescribed guidelines.

- The researcher would visit the project at least once a year to do field observations.

\section{Research approach}

A mixed method research approach involves collecting, analysing and integrating quantitative and qualitative data in a single study (Cresswell \& Plano Clark 2011). This approach was used in the investigation of the project. Since this study leant more towards the interpretive paradigm, the researcher acknowledges her 'on-going, subjective, and interpretive role' as researcher (Packer 2011: 125).

5.Romance is the top fiction genre that women would likely read (SBDC 2007:69). 


\section{The research design}

Longitudinal research provides a useful platform for 'the development of a methodological mix where neither of the two aspects alone is sufficient to produce an accurate picture of the social dynamics of the target population' (Mingione 1999:1). Using a longitudinal design can, however, be challenging because of the differences of opinion about the exact nature of a longitudinal study (Plano Clark et al. 2014). The main rationale for using a longitudinal design was that the study's aim was to examine possible behaviour change caused by an intervention in a community over time. Longitudinal research allows the researcher to detect developments or changes within a delineated population who experience the same significant life events within a given period of time. This can happen at both the group and individual levels (Ruspini 1999:222).

The essence of longitudinal studies is that they extend 'beyond a single moment in time. As a result, they can establish sequences of events' (Institute for Work and Health 2009:2). Ployhart and Vandenberg (2010:97) emphasise that a longitudinal study should contain a minimum of three repeated observations over a period of time.

Purposive sampling was deemed suitable for this study. Because of the transient nature of the research population, it was not possible to sustain a stable sample over a long period of time. Menard (1991:67) advises that where respondents are not rigidly replicated for each wave of data, the study should take place over a longer period of time and a consistent number of data collection waves should be applied to permit an in-depth, long-term analysis of social change. This study consequently stretched over five years and data was collected every month, at the end of every year and at the end of five years. The nature of the study also played a role in this decision to extend the study over time, because reading promotion projects take time to effect changes.

\section{Data collection}

Mainly qualitative data collection methods were used, namely document analysis of the monthly and yearly reports submitted by the coordinator to the researcher as well as observations by the researcher. The researcher visited the project at least once a year, when extensive field visits were conducted, and held informal discussions with the beneficiaries.

Quantitative data were collected by means of a questionnaire that was completed voluntarily by the beneficiaries of the project at the end of five years. The questionnaire also provided an opportunity to triangulate the qualitative findings to ensure reliability.

\section{Analysis of the data}

In the analysis of the qualitative data, time was treated as an ordinal variable. Data were analysed at the end of every year and arranged thematically according to predetermined themes decided on by the researcher and the coordinator as basic indicators of change. The yearly data collected under each theme were then merged and interpreted.

The quantitative data were manually analysed and quantified into percentages. Both sets of data were consequently merged to determine the similarity and/or differences in the themes. This allowed the researcher to determine the validity of the research.

The thematic coding of the data collected over the five years is presented in an extended table, allowing the reader to track the unfolding of the process. After the categorisation of data into themes, they were interpreted by both the coordinator and the researcher to gain a deeper understanding of the data.

Two dominant themes emerged from the data analysis that were not foreseen by either the researcher or the coordinator. These themes are discussed in Tables 1-8.

The number of readers attending club meetings grew from 80 in 2009 to 720 in 2013. This constitutes a growth of $80 \%$. The number of reading clubs grew from $8-18$. This significant upward trend, both in relation to the number of book clubs as well as the number of readers, is a positive indicator that the intervention was perceived in a positive light (Table 2).

Many of the club members revealed a natural aptitude to become reliable and effective facilitators. As custodians of the books, they gained status among other community members. Books became valuable items and some readers were even expelled from the book clubs because they did not take good care of the books. When a club facilitator had to vacate her position, there was always another one, equally capable, to take over.

Although a core group of members attended club meetings, the number varied because of factors such as seasonal work, personal problems and relocation (Table 3).

TABLE 1: Themes identified from monthly and yearly reports and field notes: Number of readers attending club meetings.

\begin{tabular}{ll}
\hline Year & Number of readers \\
\hline 2009 & 80 readers per month in eight clubs \\
2010 & 134 readers per month in eight clubs \\
2011 & 340 readers per month in 12 book clubs \\
2012 & 560 readers per month in 16 book clubs \\
2013 & 720 readers per month in 18 book clubs \\
\hline
\end{tabular}

TABLE 2: Themes identified from monthly and yearly reports and field notes: Management of the book clubs and books.

\begin{tabular}{ll}
\hline Year & Management \\
\hline 2009 & Facilitators were selected and trained to manage book clubs. \\
2010 & Facilitators became effective and took ownership. \\
2011 & This trend continued. \\
2012 & This trend continued. \\
2013 & This trend continued. \\
\hline
\end{tabular}


The urgency of the women to read was unexpected. It was clear that access to books was the major barrier keeping people from reading. Once this barrier was removed, it was relatively easy to convince the women that reading is enjoyable (Table 4).

Strong collaborations with other organisations developed. Apart from the main funders, who funded the project for five years, local businesses, farming associations and individuals remained solid allies. After the researcher left the project, it was taken over by the Afrikaanse Taal-en-Kultuurvereniging (ATKV), a social enterprise and cultural organisation. The coordinator still manages the project. The only difference is that there are now no financial constraints. The coordinator receives a salary as well as an allowance to buy books monthly. The rest of the collaborators, with the exception of the PUK-Kanselierstrust, are still on board. This situation provides the possibility of long-term sustainability (Table 5).

TABLE 3: Themes identified from monthly and yearly reports and field notes: Access to books.

\begin{tabular}{|c|c|}
\hline Year & Books access \\
\hline 2009 & The coordinator distributed books monthly at club meetings. \\
\hline 2010 & Books were kept at the facilitators' homes. \\
\hline 2011 & This trend continued. Readers started asking for specific books. \\
\hline 2012 & $\begin{array}{l}\text { Books started to be circulated by the coordinator from one } \\
\text { settlement to the other. }\end{array}$ \\
\hline 2013 & This trend continued. \\
\hline
\end{tabular}

TABLE 4: Themes identified from monthly and yearly reports and field notes: Collaboration and partners.

\begin{tabular}{|c|c|}
\hline Year & Collaboration and partners \\
\hline 2009 & $\begin{array}{l}\text { The main funder was the Government of Antwerp, Belgium. } \\
\text { A small truck was donated to the project by the Orange River } \\
\text { Producers Association (ORPRA) and a monthly tank of petrol } \\
\text { was donated by KLK, a farmers' cooperative. The truck was } \\
\text { necessary to travel to club meetings and transport the books } \\
\text { that needed to be exchanged. }\end{array}$ \\
\hline 2010 & $\begin{array}{l}\text { The main funder became LAPA Publishers. ORPRA and KLK } \\
\text { continued to support the project. The University of the } \\
\text { North-West's (NWU) School for Creative Writing and the PUK } \\
\text { Kanselierstrust started to supply funds and expertise. }\end{array}$ \\
\hline 2011 & $\begin{array}{l}\text { The main funder became the Dagbreektrust. NWU's aid } \\
\text { continued. Individuals and church and culture groups started } \\
\text { to donate books. }\end{array}$ \\
\hline 2012 & $\begin{array}{l}\text { The main funder remained the Dagbreektrust. NWU's aid as } \\
\text { well as donations of books by individuals and local } \\
\text { organisations continued. A big donation of books was received } \\
\text { from the Agricultural Association for Women (VLV) in Upington. }\end{array}$ \\
\hline 2013 & $\begin{array}{l}\text { The main funder was still the Dagbreektrust. Aid from NWU } \\
\text { and private donations of books continued. }\end{array}$ \\
\hline
\end{tabular}

TABLE 5: Themes identified from monthly and yearly reports and field notes: Reader development.

\begin{tabular}{ll}
\hline Year & Reader development \\
\hline 2009 & $\begin{array}{l}\text { Women were initially very shy and found it difficult to share } \\
\text { their views about the books they had read. }\end{array}$ \\
& $\begin{array}{l}\text { After they had read for a year and started to enjoy the books } \\
\text { they read, they wrote their reading experiences on a piece of } \\
\text { paper and gave it to the coordinator. She shared their thoughts } \\
\text { with the rest of the club members. }\end{array}$ \\
& $\begin{array}{l}\text { Discussing the books became easier. The women became } \\
\text { personally involved in the fictional worlds they discovered in } \\
\text { the books and identified with issues and characters in the } \\
\text { books. They discussed their own problems by referring to the } \\
\text { books they had read. }\end{array}$ \\
2012 & $\begin{array}{l}\text { Women discussed the books with self-confidence. They started } \\
\text { to collect money to buy books they wanted. They became } \\
\text { increasingly more knowledgeable about the genres and } \\
\text { authors they preferred. }\end{array}$ \\
& The trend continued. \\
\hline
\end{tabular}

Over the course of five years the women who attended the reading clubs developed from shy, uncertain readers into readers who could voice their views about contexts and characters and what they liked and didn't like. They developed a personal reading taste and applied the experiences of fictional characters to their personal worlds. They saw their society's and their own personal problems reflected in the books they read and found solutions there.

A relationship of trust developed between the coordinator and the women (Table 6).

After a period of five years a reading culture was established in these communities. This statement is supported by the results of the questionnaire. Reading motivated the women to believe in themselves. Their self-confidence grew and they realized that there are ways to improve their lives. Characters in books became role models.

The women also started to insist on reading projects for their children. The Zoë reading project for children was identified as a suitable project for these communities. Funds were sourced and found and the Zoë reading project was offered to children in some of the settlements during 2013 and 2014 (Snyman 2014).

The following two developments were added as themes to the analysis of the source documents (Table 7).

It was observed that many readers did not need or want the social activity of club meetings, but only wanted books to read. This might be an indication that a reading culture existed before the establishment of the project, but that access to books was, for many people, the only obstacle in not maintaining their reading habit. These women used the locations of the book club's books as a mini-library. The facilitators managed this process and controlled the books (Table 8).

The most surprising development in this project was how eager some women were to write. They first wrote their

TABLE 6: Themes identified from monthly and yearly reports and field notes: Changing lives: self-development.

\begin{tabular}{ll}
\hline Year & Changing lives: self-development \\
\hline 2011 & $\begin{array}{l}\text { It became clear that the women gained more self-confidence. } \\
\text { They even started to initiate reading clubs on their own. }\end{array}$ \\
2012 & Women who had never worked began to seek employment. \\
2013 & More women began working and some started studying. \\
\hline
\end{tabular}

Table 7: Themes identified from monthly and yearly reports and field notes: Readers came forward who did not attend club meetings.

\begin{tabular}{ll}
\hline Year & Readers \\
\hline 2010 & $\begin{array}{l}\text { Members of the community who were not attending the book } \\
\text { clubs started to 'take out' books. It started with about thirty } \\
\text { readers who wanted books but who did not necessarily want } \\
\text { to attend club meetings. It was decided to allow them to take } \\
\text { out books from facilitators, who were supplied with a number } \\
\text { of books. The books were carefully monitored by the } \\
\text { facilitators. }\end{array}$ \\
2011 & $\begin{array}{l}\text { This trend continued. Books kept by the book club facilitators } \\
\text { were used as a mini-library. }\end{array}$ \\
2012 & This trend continued. \\
\hline
\end{tabular}


TABLE 8: Themes identified from monthly and yearly reports and field notes: Writing development.

\begin{tabular}{|c|c|}
\hline Year & Writing development \\
\hline 2009 & $\begin{array}{l}\text { Writing started when some of the club members wrote down } \\
\text { their feelings and opinions about books on pieces of paper. }\end{array}$ \\
\hline 2010 & $\begin{array}{l}\text { This practice motivated some women to write down their own } \\
\text { life stories - especially the stories that were too difficult to talk } \\
\text { about. It became clear that many women had experienced } \\
\text { trauma in their past. }\end{array}$ \\
\hline 2011 & $\begin{array}{l}\text { Writing became more and more dominant as an activity for } \\
\text { book club members. More women began to write down their } \\
\text { own stories. Quite a few chose poetry to express their feelings. } \\
\text { Fifteen club members attended the Department of Art and } \\
\text { Culture's Writer's Festival in Kimberley, where they read their } \\
\text { own poems. } \\
\text { Stroopsoet Bitterheid ['Sweet Bitterness'], a collection of } \\
11 \text { club members' stories, was published in book form. } \\
\text { A creative writing workshop was organized with the assistance } \\
\text { of the North-West (NWU) to teach interested women writing } \\
\text { skills. This workshop became a yearly event. }\end{array}$ \\
\hline 2012 & $\begin{array}{l}\text { The trend continued. More creative writing workshops } \\
\text { followed, with the assistance of the NWU. }\end{array}$ \\
\hline 2013 & $\begin{array}{l}\text { A publication written by club members featuring stories about } \\
\text { Namaqualand, Namakwaland stories, was compiled and } \\
\text { published. Some women even attempted to submit their work } \\
\text { to publishers. }\end{array}$ \\
\hline
\end{tabular}

own tentative interpretations of the stories they had read and later their own stories. To see their names in print was, for most of them, the highlight of their lives. Writing became a way to express pain and deal with hardships, as well as to gain recognition and status among family and friends.

\section{Discussion of qualitative data}

In the documented field notes the number of book club members who improved their lives is too high to be accidental. Women who were seasonal workers started looking for more work and engaged in voluntary community work. Some found employment at their local clinics, at local cleaning projects and at road works. One of the club members, a girl in Grade 12, started her own book club in Leseding. Andrea, a Grade 3 learner, began to read to children in her community. Some women started studying. Eight women in Kalksloot finished their high school education after they became members of the book clubs and found employment. Three women completed (and one enrolled for) a diploma in Early Childhood Development. A severely traumatised woman who was in prison for murder attended the reading club meetings in prison. After her release she joined the reading club in her community. Their support helped her to gain enough self-confidence to find employment. She has now been working for two years. In another reading club a member finished her matric (Grade 12) and started her own business.

\section{Analysis of the quantitative data}

The questionnaires were made available to all the women: those who attended reading clubs and those who only borrowed books from club facilitators. They had to return the completed forms to their club facilitator. Of a possible 720 respondents, 152 completed and returned the forms (21.1\%). The data were analysed manually. The findings of the analysis based on the quantitative data are presented in the pie charts (Figure 1).
Most readers (66\%) were between 21 and 40 years of age. It is assumed that they were women who cared for children and who existed on government grants. The rest of the readers mainly fell into older age groups. They had mostly never worked and were housewives (Figure 2).

Only $25 \%$ of the readers attended book club meetings; the rest used the book clubs as a kind of 'library'. Those readers who were not members of the book clubs were partly responsible for improving the reading culture in the community (Figure 3).

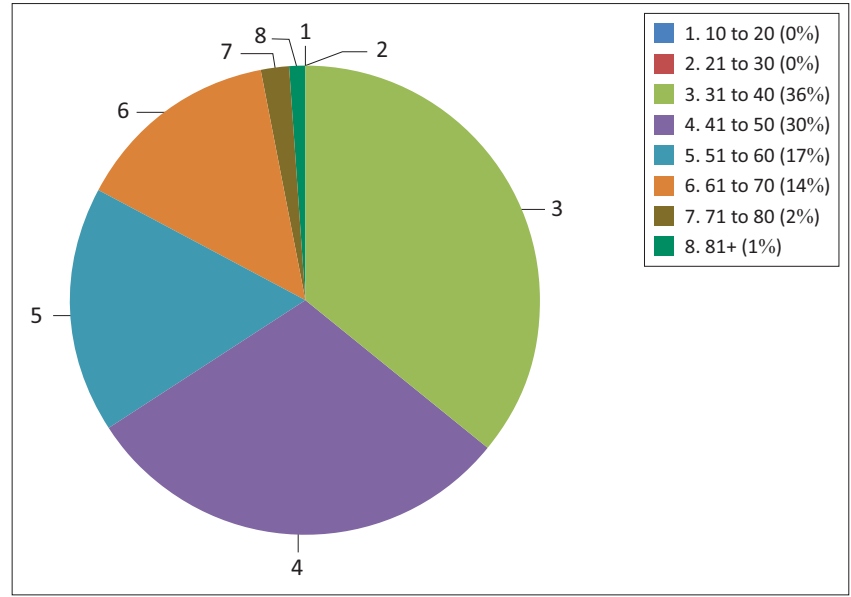

FIGURE 1: The distribution of the research participants' ages.

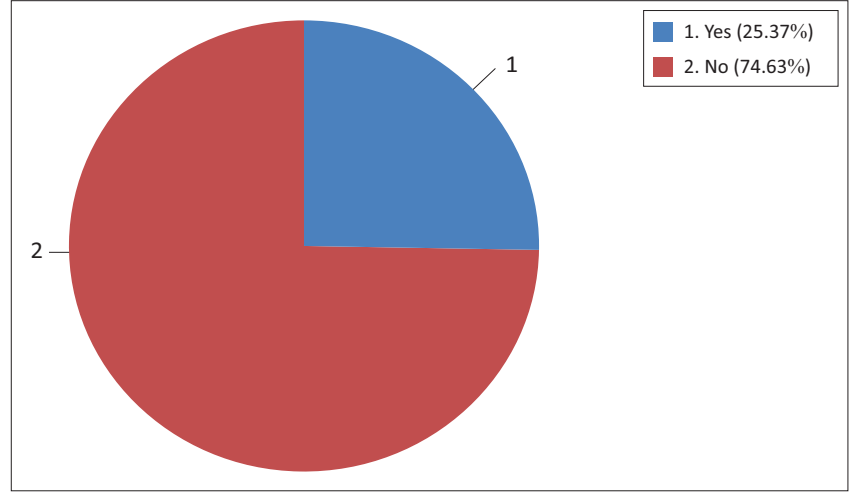

FIGURE 2: The number of readers who attended the book club meetings in 2013.

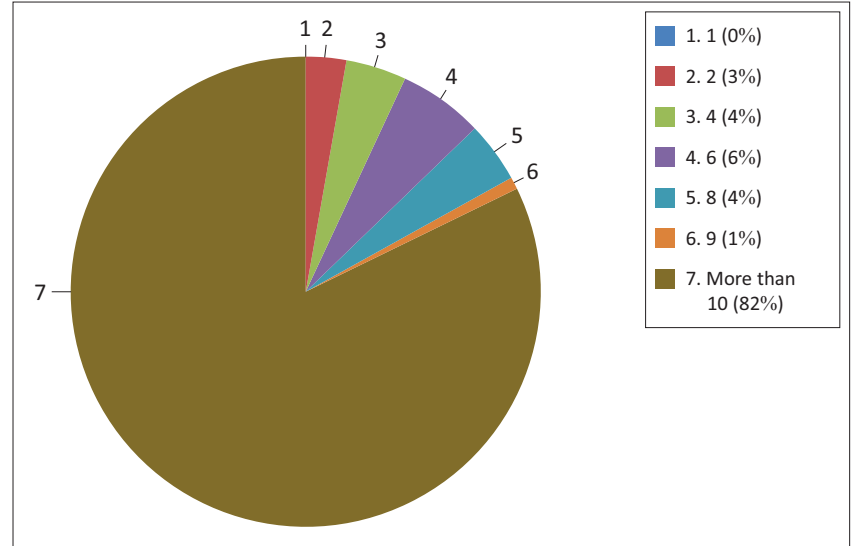

FIGURE 3: Number of books that were read per month. 
More than $80 \%$ of the women read more than ten books per month. Reading increased dramatically; it seems as if the women could not get enough. These findings recall Sisulu's phrase, 'book hunger' (2004) (Figure 4).

Almost $80 \%$ read to escape, mostly from unsatisfactory living conditions and broken relationships. The other 20\% were women who lived comfortably and read to while away the time (Figure 5).

Conforming to global statistics the preferred genre (70\%) was the romance. Murder mysteries (16\%) were in second place. The indication that $8 \%$ of the readers liked teenage novels is a positive sign of an improved reading culture. It means that younger readers are also starting to read (Figure 6).

Thirty-four per cent indicated that they would be idle because they would have nothing to do; 30\% described themselves as lovers of reading and $24 \%$ read to escape. Reading is obviously an important factor in their lives.

\section{Merging of data}

The findings of the questionnaire supported and validated the findings of the qualitative data and no incongruences were found.

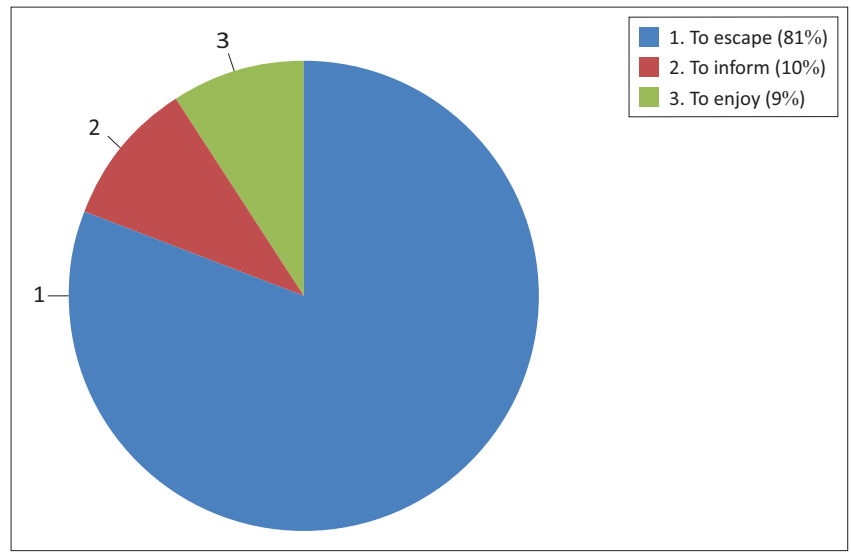

FIGURE 4: Reasons why the women read.

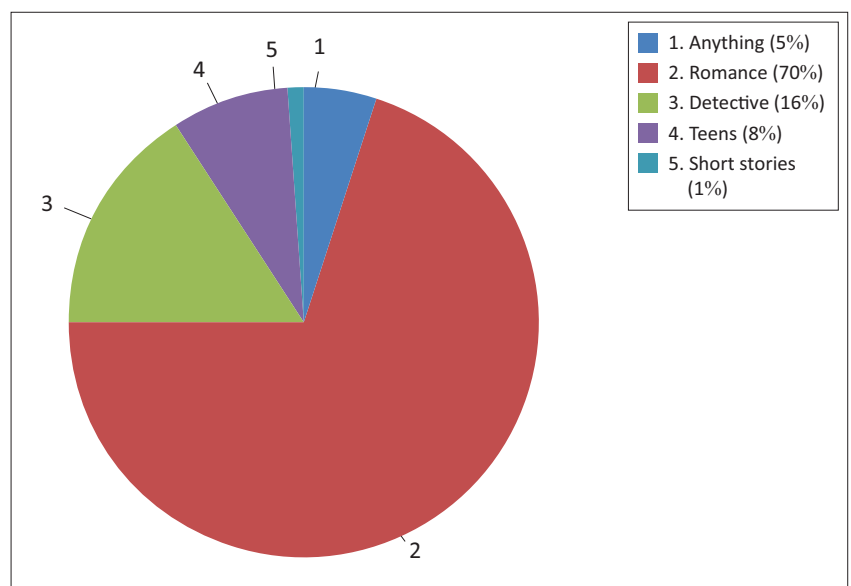

FIGURE 5: Reading preferences of the research participants.

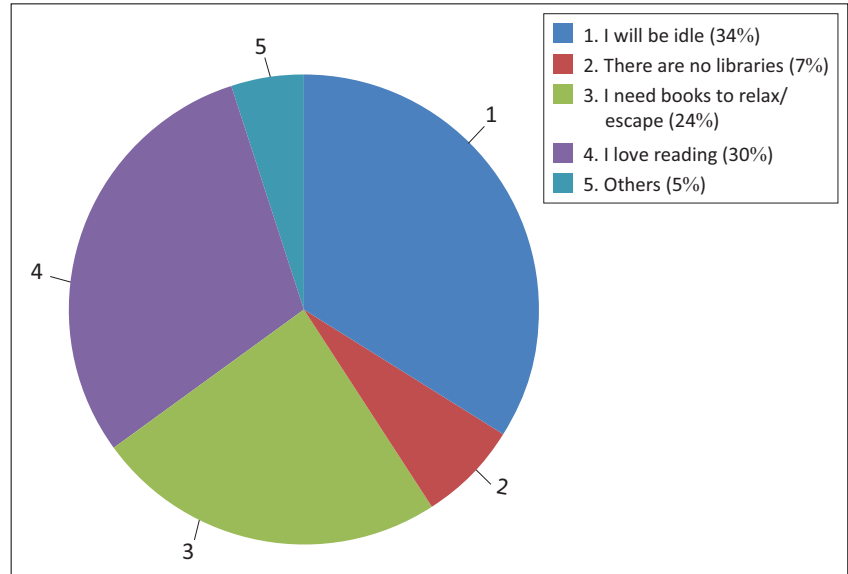

FIGURE 6: Responses to the question, 'How will you feel if the reading project is terminated?

\section{Discussion of the effects of the reading promotion project}

There can be little doubt that reader development was an outcome of this reading promotion project and that in some cases reader development, indeed, led to self-development. The reading promotion project had an overall positive effect in the community. Women started reading, working, studying and inspiring their children to read. In more than half of the reading clubs the development of a greater sense of self-value was visible. This change can be inferred from the activities the women became involved in. Not all women displayed a positive change, however. In some clubs few women showed independence and expected the coordinator to keep nurturing them. Yet reading in a social setting, even if it was just getting books from a familiar face, had a positive impact on the readers' self-esteem and behaviour.

The development of this reading project indicated that the lack of a reading culture was mostly caused by the lack of a conducive reading environment (Oyegade 2012:61). The lack of access to appropriate reading material was the most important barrier to a reading culture. It was an easy matter for the enthusiastic coordinator to unlock the pleasure of reading for the beneficiaries.

The fact that the beneficiaries were mostly literate played a decisive role in the positive outcome of the project. Illiterate or semi-literate research participants would probably have yielded different results. This fact implies that more research is needed. It would also be interesting to compare the impact of reading clubs currently being established in developing communities in South Africa with the impact of South African reading English clubs in the previous century. This research also revealed the lack of existing indicators to evaluate reading promotion projects. This is another area of further research. A content analysis of the stories written by these women could expose the effects of abuse and poverty in their existence.

\section{Conclusion}

This study revealed that poverty means hours of empty days and nights with nothing to do and that books can fill these 
hours and change people's lives. Although Snyman (2006) in her study of the reading habits of Afrikaans children also found that boredom was the best motivator for reading, this study's finding that reading has an overall positive effect on disadvantaged readers must be noted.

Well-stocked libraries and mobile libraries within reach of South Africa's people can contribute to strengthening the human fabric of South Africans and should become a primary objective of government. The negligence of government to provide access to books should be addressed. Interestingly, the success of this project has motivated the DAC to investigate the possible establishment of libraries at some of the locations where the reading clubs are. Kulsen told the researcher on 07 April 2015 that the DAC is talking about appointing the facilitators of the reading clubs to work in the proposed libraries. Whether this turn of events is good or bad remains to be seen. Libraries need librarians, and the role of the coordinator in the success of the project should not be underestimated. Sustained enthusiasm and passion are needed in reading promotion (Rimmensberger 2014:3).

The message is evident: It is possible to create a reading culture where none exists, but creating a reading promotion project that continues to foster a reading culture needs time, money and mostly enthusiasm. This research has further shown that South Africa has the human capital and that good leadership can unlock it.

\section{Acknowledgements Competing interests}

The author declares that she has no financial or personal relationships that may have inappropriately influenced her in writing this article.

\section{References}

//Khara Hais Municipality, 2014, Integrated development plan 2012-2017. Draft review for 2014/2015. Financial review, viewed 2 March 2105, from http:// mfma.treasury.gov.za/Documents/01.\%20Integrated\%20Development $\% 2$ Plans/2014-15/02\%20Local\%20Municipalities/NC083\%20Khara\%2OHais/ NC083\%20Khara\%20Hais\%20Drft\%20IDP\%20Review\%202014-15.pdf

Bayless, C., 2010, 'Growing a reading culture: just for parents', Atlanta, in Through the magic door, viewed 12 April 2015, from http://www.slideshare.net/ ThroughtheMagicDoor/growing-a-reading-culturereport

Benevides, T. \& Peterson, S.S., 2010, 'Literacy attitudes, habits and achievements of future teachers', Journal of Education for Teaching: International Research and Pedagogy 36(3), 289-302, viewed 18 April 2015, from http://www.tandfonline. com/doi/abs/10.1080/02607476.2010.497375

Chizwina, R.S., 2011, 'An exploratory investigation into the status of reading promotion projects in South Africa', Masters dissertation, Dept. of Information Science, University of Pretoria.

Cox, K. \& Guthrie, J.T., 2001, "Motivational and cognitive contributions to students' amount of reading', Contemporary Educational Psychology 26, 11-31.

Cresswell, J.W. \& Plano Clark, V., 2011, Designing and conducting mixed method research, 2nd edn., Sage, Thousand Oaks.

Department of Arts and Culture, 2014, The library and information services transformation charter, DAC, Pretoria, viewed 14 October 2013, from www.nlsa. ac.za/Downloads.../2014_Final_LIS_Transformation_Charter

Department of Basic Education, 2012, Diagnostic report: Annual national assessment, $\mathrm{DBE}$, Pretoria.

Department of Culture, Media and Sport, 2003, Framework for the future: Libraries, learning and information in the next decade, DCMS, London.
Doiron, R. \& Asselin, M, 2011, 'Promoting a culture for reading in a diverse world', International Federation of Library Associations and Institutions 37(2), world', Inter.

Elkin, J., Train, B. \& Denham, D., 2003, Reading and reader development: the pleasure of reading, Facet, London.

Equal Education, 2009, We can't afford not to, viewed 14 May 2014, from www. equaleducation.org.za/.../2011-11-15-We_Cant_Afford_Not_To_2

EU high level group of experts on literacy, 2012, Final report, viewed 24 March 2015, from ec.europa.eu/education/.../literacy-report_en.pdf

Gallagher, K., 2009, Readicide: How schools are killing reading and what you can do about it, Steinhouse Publishers, New York.

Hart, G. \& Nassimbeni, M., 2013, 'From borders and landscape to ecosystem: Reconfiguring library services to meet the needs of South African youth', South African Journal for Library and Information Science 79(1), 13-21.

Institute for Work and Health, 2009, At Work, Issue 55, Winter, IWM Institute for Work and Health, Toronto, viewed 16 April 2015, from http://www.iwh.on.ca/wrmb/ cross-sectional-vs-longitudinal-studies

ITS \& SANRAL, 2007, Special development project: Siyanda district municipality, viewed 2 March 2015, from http://www.nra.co.za/content/Siyanda1.pdf

KPMG, 2008, Department of arts and culture: Status quo report', viewed 24 February 2010, from http://www.dac.gov.za/projects/nclis/DAC $\% 20 \% 20$ Public $\% 2$ 20library\%20funding $\% 20$ model $\% 20 \% 20$ Phase $\% 202 \% 20 \_$Report $\% 20$ Public\%20library\%20funding $\% 2$ model $\% 20 \% 20$ disclaimer.pdf
2\%20of\%203_\%20final\%20\%20dis

Leadbeater, C., 2003, Overdue: How to create a modern public library service, Demos, London.

Machet, M. \& Tiemensma, L., 2009, 'Literacy environment in support of the development of literacy skills and voluntary reading', Mousaion 27(2), 58-76.

Malmgren, K. W. \& Leone, P.W., 2000, 'Effects of a short-term auxiliary reading program on the reading skills of incarcerated youth', Education and Treatment of Children 23(3), 239-247, viewed 2 February 2015, from http://www.jstor.org/ stable/42899617

Menard, S., 1991, Longitudinal research, Sage Publications, Newbury Park.

Mingione, E., 1999, 'Foreword. Longitudinal research: A bridge between quantitative and qualitative social research?', in E. Ruspini (ed.), 'Longitudinal analysis: a bridge between quantitative and qualitative social 'research', special issue of Quality and Quantity, 33(3), July-August.

Mokhtari, K., Reichard, C.A. \& Gardner, A., 2009, 'The impact of internet and television use on the reading habits and practices of college students', Literary Research and Instruction 48, 264-247, viewed 14 April 2015, from http://dx.doi.org/10.1598/ JAAL.52.7.6

Mulgrew, N., 2012, 'National literacy: Once upon a time, parents taught their children to read', Mail \& Guardian, 19 October, p.14.

Olaofe, I, 2003, 'Building a reading culture in communities where adverse situations thrive', in A. Arua (ed.), Reading for all in Africa: Building communities where literacy thrives, pp. 97-99, International Reading Association, Newark.

Oyegade, E.A., 2012, 'Reading promotion campaign activities of the Oyo State Library Board, Ibadan', in D. Rosenberg (ed.), Reader development and reading promotion:
Recent experiences from seven countries in Africa, International Network for the Recent experiences from seven countries in $A$
Availability of Scientific Publications, Oxford.

Packer, M., 2011, The science of qualitative research, Cambridge University Press, New York.

Phasha, N.T., McLure, L. \& Magano, M., 2012, 'The book and the banknote: Reading for leisure amongst 10th grade learners in South Africa', Anthropologist: International Journal of Contemporary and Applied Studies of Man 14(4), 319-326.

Plano Clark, V., Anderson, N., Wertz, J. A., Zhou, Y. \& Schumacher, K., 2014 'Conceptualising longitudinal mixed method designs: A methodological review of health sciences research', Educational Psychology Papers and Publications, Paper 160, viewed 22 April 2015, from http://digitalcommons.unl. edu.edupsychpapers $/ 160$

Ployhart, R. E. \& Vandenberg, R.J., 2010, 'Longitudinal research: the theory, design and analysis of change', Journal of Management 36(1), 94-120.

Pretorius, E.J. \& Currin, S., 2010, 'Do the rich get richer and the poor poorer? The effects of an intervention programme on reading in the home and school language in a high poverty multilingual context', International Journal of Educational Development 30,67-76, viewed 16 April 2015, from http://www. sciencedirect.com/science/article/pii/S0738059309000741

Rimmensberger, N., 2014, 'Reading is very important, but ... Taking stock of South African student teachers' reading habits', Reading and Writing 5(1), 1-9. $\mathrm{http} / / \mathrm{dx}$.doi.org/10.4102//rw.v511.50

Rosi, M., 2005, Book donations for development, UNESCO, Toronto.

Ruspini, E. (ed.), 1999,'Longitudinal analysis: A bridge between quantitative and qualitative social research?', Quality and Quantity 33(3), July-August.

Sisulu, E., 2004, 'The culture of reading and the book chain: How do we achieve a quantum leap?', viewed 28 July 2006, from http://www.centreforthebook.org.za/ events/culture_reading.html

Snyman, M., 2006, 'Die leesvoorkeure en -gedrag van Afrikaanse kinders', Mousaion 24(3), 145-179.

Snyman, M., 2014, 'Die evaluering van 'n leesbevorderingsprojek: die Zoëvoorleesprojek in die Noord-Kaap', Mousaion: Edition on Children's Literature and Reading 34(4), 55-75. 
South African Book Development Council, 2007, National survey into the reading and book reading behaviour of adult South Africans: Quantitative research into the reading and book buying habits of adult South Africans from age 16, Print Industries Council, Dept of Arts and Culture, Pretoria.

SouthAfrica.info, 2015, viewed 14 April 2015, from http://www.southafrica.info/ community/using-sainfo-material.htm\#.VLi4pU107cs\#ixzz3OxwbPvwH
Spaull, N., 2013, South Africa's education crisis: The quality of education in South Africa 1994-2011. A report commissioned by the Centre for Development and Enterprise, October, viewed 22 April 2015, from www.uj.ac.za/.../Centresandlnstitutes/.../ ELI\%20S

The Local Government Handbook: A complete guide to municipalities in South Africa 2015, viewed 03 March 2015, from http://www.localgovernment.co.za/ 